\title{
PENGARUH PENGGUNAAN METODE EKSPERIMEN TERHADAP HASIL BELAJAR SISWA PADA MATA PELAJARAN IPA DI KELAS V SD NEGERI 101790 MARINDAL II KECAMATAN PATUMBAK
}

\author{
Rinci Simbolon ${ }^{1)}$ Winda sahpitri br sitepu ${ }^{2)}$ \\ ${ }^{1}$ Dosen Universitas Quality, ${ }^{2)}$ Alumni Mahasiswa Universitas Quality \\ Email : Rinci_S@Yahoo.com
}

\begin{abstract}
Permasalahan dalam penelitian ini adalah hasil belajar siswa belum maksimal. Tujuan dari penelitian ini adalah untuk mengetahui hasil belajar siswa dan pengaruh penggunaan metode eksperimen terhadap hasil belajar siswa pada mata pelajaran IPA di kelas V Tahun Ajaran 2017/2018. Jenis penelitian ini adalah quasi eksperimen. Penelitian ini dilaksanakan di SD Negeri 101790 Marindal II Kecamatan Patumbak. Populasi penelitian ini adalah seluruh siswa kelas V SD Negeri 101790 Marindal II Kecamatan Patumbak yang berjumlah 51 siswa sekaligus menjadi sampel penelitian yang terbagi menjadi dua kelas pararel. Alat pengumpulan data yang digunakan adalah berupa test dan analisis data yang digunakan adalah uji normalitas, uji homogenitas dan pengujian hipotesis digunakan uji independen antara dua faktor.
\end{abstract}

Dari hasil analisis data diperoleh bahwa hasil belajar siswa pada mata pelajaran IPA materi sifat-sifat cahaya tidak sama setelah menggunakan metode eksperimen di kelas V SD Negeri 101790 Marindal II Kecamatan Patumbak, diperoleh nilai rata-rata 76,80 dan hasil belajar siswa pada mata pelajaran IPA materi sifat-sifat cahaya tidak sama meningkat setelah menggunakan pembelajaran konvensional di kelas V SD Negeri 101790 Marindal II Kecamatan Patumbak, diperoleh nilai rata-rata 62,42. Dan hasil belajar siswa pada mata pelajaran IPA materi sifat-sifat cahaya menggunakan metode eksperimen lebih baik dari pada menggunakan pembelajaran konvensional di kelas V SD Negeri 101790 Marindal II.

\section{Kata kunci : Hasil belajar, Metode eksperimen}

\section{ABSTRACT}

The problem in this research is the result of student learning has not been fullest. The purpose of this research is to know the results of student learning and influence the use of experimental methods towards learning outcomes students on subjects natural science material properties of light in class V 2017/2018 academic year.This type of research is quasi experiment. This research is carried out in SD Negeri 101790 Marindal II Patumbak Sub-district. The population of this research is the whole grade V SD Negeri 101790 Marindal II Patumbak Subdistrict of 51 students all at once into the research sample is divided into two 
parallel classes. Data collection tool used is a form of test and analysis of the data used is test, test of its homogeneity and normality and hypothesis testing to use independent test between two factors.

Data analysis of the results obtained that the results of student learning on subjects natural science Material properties of light are not the same after using the experimental method in the class V SD Negeri 101790 Marindal II Patumbak Sub-district, the values obtained the average student learning outcomes and 76.80 on subjects natural science material properties of light are not the same increased after using conventional learning in class V SD Negeri 101790 Marindal II Patumbak Subdistrict, obtained average value of 62.42. And the results of student learning on subjects natural science material properties of light using experimental methods better than using conventional learning in class V SD Negeri 101790 Marindal II 2017/2018 Patumbak Sub-district.

\section{Keywords: results of the study, Experimental Methods}

\section{PENDAHULUAN}

\begin{abstract}
Pendidikan Nasional berfungsi mengembangkan kemampuan dan membentuk watak serta peradaban bangsa yang bermartabat dalam rangka mencerdaskan kehidupan bangsa, bertujuan untuk berkembangnya potensi peserta didik agar menjadi manusia yang beriman dan bertakwa kepada Tuhan Yang Maha Esa, berakhlak mulia, sehat, berilmu, cakap, kreatif, mandiri, dam menjadi warga negara yang demokratis serta bertanggung jawab. Faktor domain yang perlu diperhatikan juga dalam keberhasilan pendidikan adalah proses pembelajaran, terutama dalam proses pembelajaran IPA di SD karena pendidikan IPA di SD memiliki peran yang penting dalam menyiapkan anak memasuki dunia kehidupannya.
\end{abstract}

Dalam proses pembelajaran terjadi interaksi antara guru dan siswa. Dimana guru sebagai fasilitator sedangkan siswa sebagai subjek didik untuk mencapai suatu tujuan pendidikan. Untuk meningkatkan pendidikan harus mempunyai upayaupaya positif dan memiliki media pembelajaran yang digunakan dalam proses pembelajaran di kelas. Dalam proses pembelajaran IPA hendaknya disediakan serangkain pengalaman berupa kegiatan nyata yang rasional atau dapat dimengerti oleh siswa dan memunginkan terjadi interaksi sosial. Jadi saat proses pembelajaran siswa harus terlibat secara langsung dalam kegiatan nyata siswa memperoleh pembelajaran dengan baik.

Namun kenyataan di lapangan, khususnya di SD Negeri 101790 Marindal II Kecamatan Patumbak berdasarkan informasi dari guru kelas $\mathrm{V}$ bahwa dalam pembelajaran IPA lebih menekankan pada metode ceramah dan pemberian tugas. Sedangkan penggunaan media pembelajaran masih jarang digunakan, hal ini terlihat dari nilai harian rata-rata nilai IPA masih belum maksimal yaitu 70 sesuai KKM yang diterapkan disekolah. Sebagai gambaran dapat dilihat di tabel data nilai mata pelajaran IPA siswa V SD Negeri 101790 Marindal II Kecamatan Patumbak. 
Tabel 1.1 Hasil Belajar Mata Pelajaran IPA Siswa Kelas V 101790 Marindal II Kecamatan Patumbak

\begin{tabular}{|c|c|c|c|c|}
\hline KKM & Nilai & $\begin{array}{c}\text { Jumalah } \\
\text { Siswa }\end{array}$ & $\begin{array}{c}\text { Persentase } \\
(\%)\end{array}$ & Keterangan \\
\hline \multirow{3}{*}{70} & $\geq 70$ & 33 & $65 \%$ & Tidak tuntas \\
\cline { 2 - 4 } & $<70$ & 18 & $35 \%$ & secara klasikal \\
\cline { 2 - 4 } & Jumlah & 51 & $100 \%$ & \\
\hline
\end{tabular}

\section{Sumber Data: SD Negeri 101790 Marindal II Kecamatan Patumbak}

Berdasarkan data yang diperoleh menunjukkan bahwa dari 51 siswa yang tuntas di atas KKM adalah sebanyak 33 siswa (65\%) dan tidak tuntas belajarnya sebanyak 18 siswa $(35 \%)$. Nilai dikatakan tuntas apabila mencapai KKM yang telah di tetapkan oleh sekolah yaitu 70 . Berdasarkan masalah tersebut, untuk meningkatkan hasil belajar siswa dan menciptakan suasana yang menarik di dalam kelas, guru perlu menggunakan metode eksperimen khususnya pada materi sifat-sifat cahaya yang berguna untuk mempermudah guru dalam menjelaskan materi, tentunya siswa juga akan lebih termotivasi, paham dan tertarik dengan penggunakan metode eksperimen, sehingga mengubah suasana pembelajaran yang melibatkan siswa lebih aktif.

Menurut Syaiful Bahri (2014:84) menyatakan bahwa : Metode Eksperimen adalah cara penyajian pelajaran, dimana siswa melakukan percobaan dengan mengalami dan membuktikan sendiri sesuatu yang dipelajari. Menurut Sumiati (2013:101) menyatakan bahwa : Metode Eksperimen yaitu percobaan tentang sesuatu. Dalam hal ini setiap siswa melakukan percobaan dan bekerja sendirisendiri. Pelaksanaan eksperimen lebih memperjelas hasil belajar, karena setiap siswa mengalami melakukan kegiatan percobaan.

\section{METODE}

Penelitian ini telah dilaksanakan di SD Negeri 101790 Marindal II Kecamatan Patumbak. Yang menjadi populasi dalam penelitian ini adalah seluruh siswa kelas V SD Negeri 101790 Marindal II Kecamatan Patumbak berjumlah 51 orang yang terbagi menjadi dua kelas paralel. sampel dalam penelitian ini yaitu seluruh anggota populasi atau sampel total yang berjumlah 51 siswa yang terdiri dari 2 kelas yaitu kelas VA dan Kelas VB SD Negeri 101790 Marindal II Kecamatan Patumbak. Jenis penelitian yang digunakan dalam penelitian ini adalah quasi eksperiment (eksperimen semu) dengan menggunakan metode pembelajaran eksperimen dan pembelajaran Konvensional di kelas V SD Negeri 101790 Marindal II Kecamatan Patumbak. desain yang digunakan dalam penelitian ini yaitu pre test dan post test. Alat pengumpulan data yang digunakan dalam penelitian adalah tes berbentuk essay, yang terdiri 4 butir soal yang dibatasi pada ranah kognitif $\mathrm{C} 1$ dan $\mathrm{C} 2$. Teknik analisis data yang dilakukan berdasarkan hasil pre test dan post test yang dilakukan penelitian di prosedur penelitian: (1) Analisis data pre test Yaitu uji normalitas, uji homogenitas dan uji independen dua faktor pre test pada kelas yang diajarkan untuk mengetahui kesetaraan hasil belajar siswa dalam materi sifat-sifat cahaya.

(2) Analisis data post test Yaitu uji normalitas, uji homogenitas dan uji independen antara dua faktor. pre test pada kelas yang diajarkan menggunakan Metode Eksperimen . Kemudian dilakukan uji hipotesis

\section{HASIL DAN PEMBAHASAN \\ Hasil penelitian \\ Deskripasi Data Hasil Pre Test Kelas V-a}


Peneliti memberikan pre test di kelas $\mathrm{V}$-a nilai tertinggi pada pre test dikelas $\mathrm{V}$-a adalah 38,00 dan nilai terendah adalah 14,00 . Simpangan baku adalah 8,70. Untuk menyajikan data pre test kelas $\mathrm{V}$-a yang telah disusun pada gambar diagram batang, sumbu mendatar untuk menyatakan nilai siswa, dan sumbu tegak untuk menyatakan frekuensi nilai yang diperoleh setiap siswa, sebagai berikut:

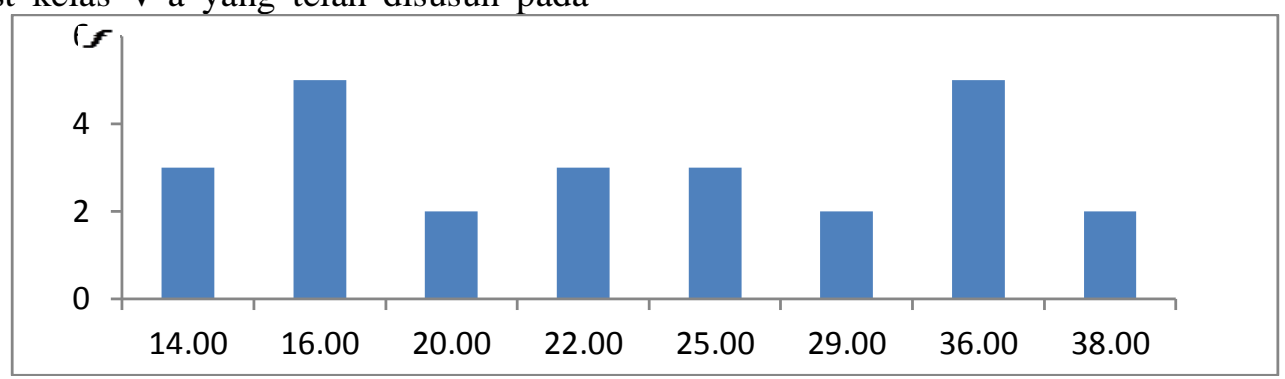

\section{Gambar 4.1 Diagram Batang Data Hasil Nilai Pre Test Kelas V-a}

Berdasarkan gambar diagram batang di atas menjelaskan bahwa sumbu mendatar untuk menyatakan nilai yang telah diperoleh siswa dan sumbu tegak untuk menyatakan frekuensi nilai siswa. Sebanyak 3 orang siswa yang memperoleh nilai 14,5 orang siswa memperoleh nilai 16,2 orang siswa memperoleh 20, 3 orang siswa memperoleh nilai 22,3 orang siswa memperoleh nilai 25,2 orang siswa memperoleh nilai 29,5 orang siswa memperoleh nilai 36 dan 2 orang siswa memperoleh nilai 38. Jumlah seluruh siswa sebanyak 25 siswa.

\section{Deskripasi Data Hasil Pre Test Kelas V-b}

Setelah diberi pre test di kelas $\mathrm{V}-\mathrm{a}$, selanjutnya peneliti memberikan pre test dikelas V-b, selanjutnya peneliti menganalisis hasil pre test dari kelas $\mathrm{V}$ b. Nilai tertinggi pada pre test di kelas V-b adalah 36,00 dan nilai terendah adalah 8,00 , simpangan baku pre test kelas V-b adalah 8,95. Yang menjadi diagram batang, sumbu mendatar untuk menyatakan nilai siswa dan sumbu tegak untuk menyatakan frekuensi nilai dalam bentuk diagram batang sebagai berikut:

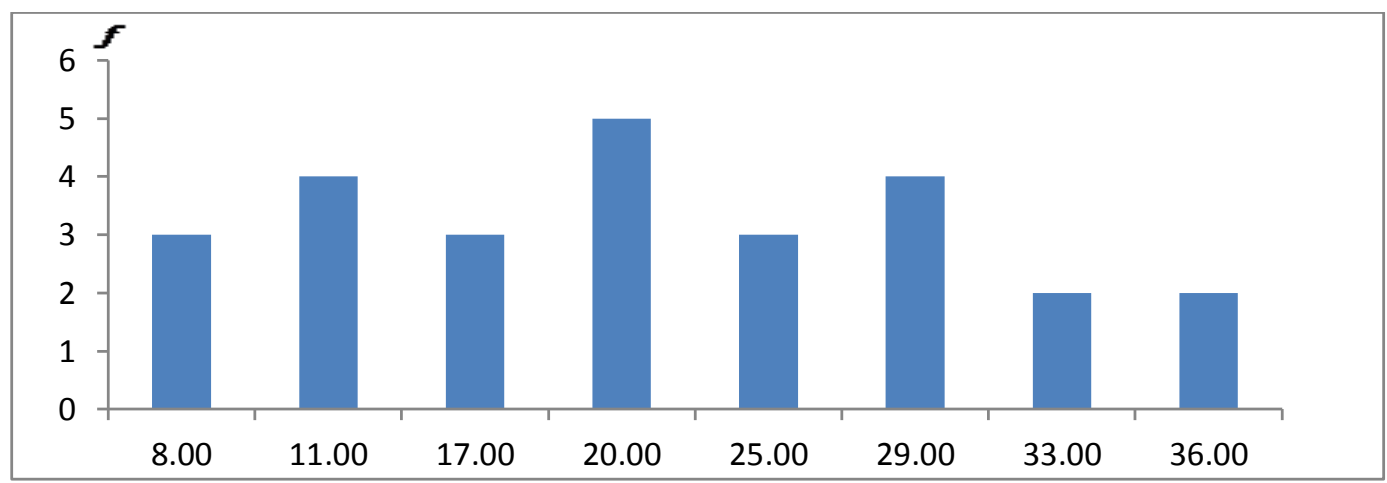

Gambar 4.2 Diagram Batang Data Hasil Nilai Pre Test Kelas V-b

Berdasarkan gambar diagram batang di atas menjelaskan bahwa sumbu mendatar untuk menyatakan nilai yang telah diperoleh siswa dan sumbu tegak untuk menyatakan frekuensi nilai siswa. Sebanyak 3 orang siswa yang memperoleh nilai 8,4 orang siswa memperoleh nilai 11,3 orang siswa memperoleh 17,5 orang siswa memperoleh nilai 20,3 orang siswa memperoleh nilai 25,4 orang siswa memperoleh nilai 29,2 orang siswa 
memperoleh nilai 33 dan 2 orang siswa memperoleh nilai 36 . Jumlah seluruh siswa sebanyak 26 siswa.

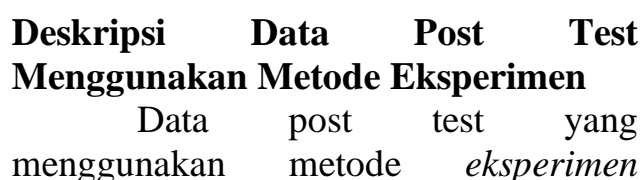
peneliti menganalisis hasil post test dari kelas V-a. Nilai tertinggi pada post test di kelas yang menggunakan metode eksperimen adalah 95, dan nilai terendah hasil post test di kelas yang menggunakan metode eksperimen adalah 53. Simpangan baku adalah 11,24 , untuk menyajikan data yang telah disusun menjadi diagram batang, sumbu mendatar untuk menyatakan nilai post test menggunakan metode eksperimen dan sumbu tegak menyatakan frekuensi nilai siswa, sebagai berikut

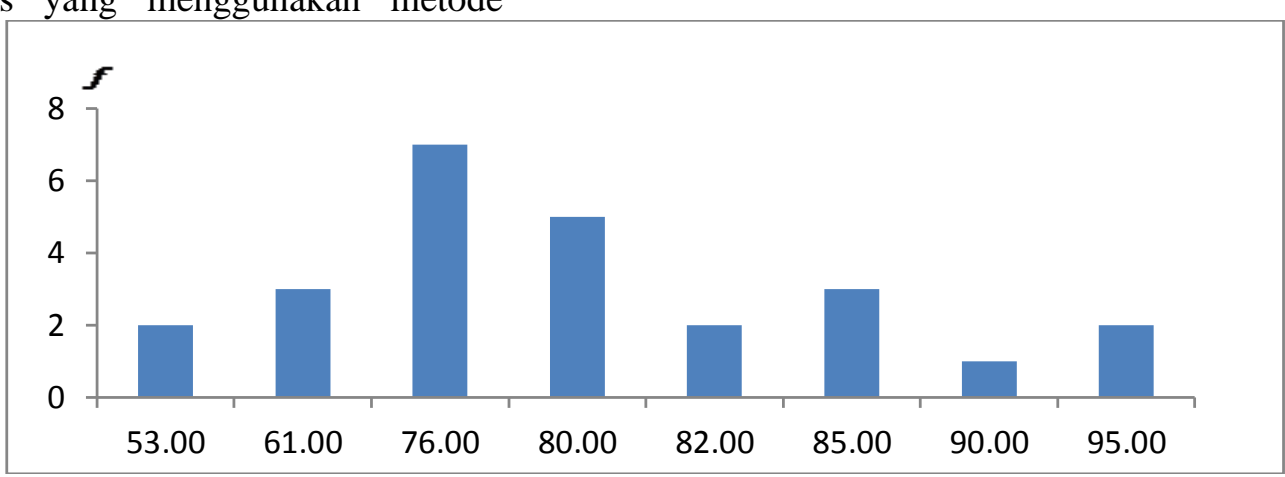

\section{Gambar 4.3 Diagram Batang Data Nilai Post Test Mengguankan Metode Eksperimem}

\begin{abstract}
Berdasarkan gambar diagram batang di atas menjelaskan bahwa sumbu mendatar untuk menyatakan nilai yang telah diproleh siswa dan sumbu tegak untuk menyatakan frekuensi nilai siswa. Sebanyak 2 orang siswa yang memperoleh nilai 53,3 orang siswa memperoleh nilai 61,7 orang siswa memperoleh nilai 76,5 orang siswa memperoleh 80,2 orang siswa memperoleh nilai 82,3 orang siswa memperoleh nilai 85,1 orang siswa memperoleh 90 dan 2 orang siswa memperoleh nilai 95. Jumlah seluruh siswa sebanyak 25 .
\end{abstract}

\section{Deskripsi data post test kelas yang menggunakan pembelajaran konvensional}

Setelah diberi post test di kelas yang menggunakan metode eksperimen, selanjutnya peneliti menganalisis hasil post test di kelas yang menggunakan konvensional. Nilai tertinggi adalah 86 dan nilai terendah adalah 42. Simpangan baku pada pembelajaran konvensional adalah 14,45 , untuk menyajikan data yang telah disusun menjadi diagram batang, sumbu mendatar untuk menyatakan nilai post test pembelajaran konvensional dan sumbu tegak menyatakan frekuensi nilai siswa, sebagai berikut: 


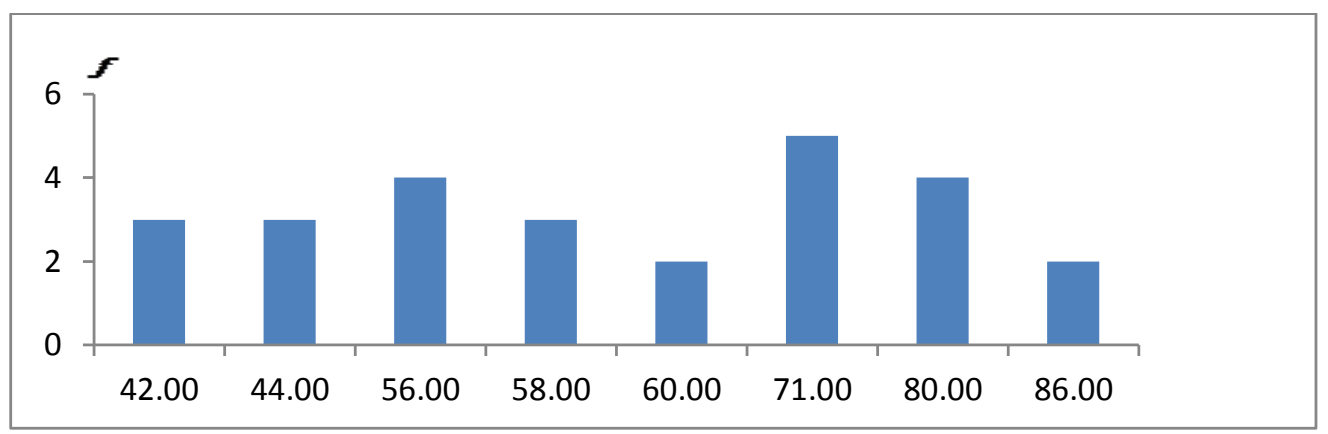

\section{Gambar 4.4 Diagram Batang Data Nilai Post Test Menggunakan Pembelajaran Konvensional}

Berdasarkan gambar diagram batang di atas menjelaskan bahwa sumbu mendatar untuk menyatakan nilai yang telah diperoleh siswa dan sumbu tegak untuk menyatakan frekuensi nilai siswa. Sebanyak 3 orang siswa yang memperoleh nilai 42,3 orang siswa memperoleh nilai 44,4 orang siswa memperoleh nilai 56,3 orang siswa memperoleh 58, 2 orang siswa memperoleh nilai 60,5 orang siswa memperoleh nilai 71,4 orang siswa memperoleh 80 dan 2 orang siswa memperoleh nilai 86. Jumlah seluruh siswa sebanyak 26

\section{Uji Persyaratan Analisis} Uji Normalitas Data

Uji normalitas data dua kelas sampel yaitu kelas menggunakan metode eksperimen dan kelas yang menggunakan pembelajaran konvensional yang dihitung menggunakan lilliefors dapat dilihat padaa tabel berikut:

Tabel 4.3 Ringkasan Nilai Uji Normalitas Data

\begin{tabular}{|c|c|c|c|}
\hline Kelas & $L_{0}$ & $L_{\text {tabel }}$ & Kesimpulan \\
\hline Metode Eksperimen & 0,1207 & 0,173 & Normal \\
\hline $\begin{array}{c}\text { Pembelajaran } \\
\text { konvensional }\end{array}$ & 0,1444 & 0,171 & Normal \\
\hline
\end{tabular}

Dari perhitungan analisis data post test pada kelas yang menggunakan metode eksperimen diperoleh harga lilliefors $\quad L_{o}=0,1207<L_{\text {tabel }}=$ 0,173 , kesimpulannya $H_{1}$ diterima maka

dapat dinyatakan data kelas yang menggunakan metode eksperimen berdisteribusi normal.

Dan dari analisis data post test pada kelas yang menggunakan pembelajaran konvensional diperoleh harga lilliefors $L_{o}=0,1444<L_{\text {tabel }}=$
0,171 kesimpulannya $\quad H_{1}$ diterima, maka dapat dinyatakan data kelas yang menggunakan pembelajaran konvensional berdistribusi normal.

\section{Uji Homogenitas Varians}

Setelah dilakukan uji normalitas data, selanjutnya dilakukan uji homogenitas data post test untuk mengetahui populasi varians yaitu untuk mengetahui apakah data tersebut mempunyai varians yang sama atau berbeda. Hasil perhitungan untuk uji homogenitas data post tes dapat dilihat pada tabel 4.4 berikut

Tabel 4.4 Ringkasan Nilai Uji Homogenitas Varians

\begin{tabular}{|l|l|l|c|c|}
\hline \multicolumn{1}{|c|}{ Kelas } & $S$ & $S^{2}$ & \multirow{2}{*}{$F_{\text {hitung }}$} & $F_{(0,05)(24,25)}$ \\
\cline { 1 - 3 } Metode Eksperimen & 11,24 & 126,3376 & & \\
\cline { 1 - 3 } Pembelajaran Konvensional & 14,45 & 208,8025 & 1,65 & 1,96 \\
\hline
\end{tabular}


Tabel uji hipotesis pada kelas yang mengguanakan metode eksperimen dan yang menggunakan pembelajaran konvensional diperoleh $F_{\text {hitung }}=1,65$ dengan $d k_{1}=n_{1}-1$ dan $d k_{2}=n_{2}-1$ hasil nilai tabel distribusi $\mathrm{F}$ untuk pembilang dan penyebut maka $F_{(0,05)(24,25)}=1,96$

$$
\text { Karena } \quad F_{\text {hitung }}=1,65<
$$

$F_{(0,05)(24,25)}=1,96$ maka $H_{0}$ diterima dapat disimpulkan data bersifat homogen.
Setelah data post test kelas yang menggunakan metode eksperimen dan kelas yang menggunakan pembelajaran konvensional sudah berdistribusi normal dan homogen maka dilakukan uji independen antara dua faktor. Untuk mengetahui berpengaruh tidaknya pembelajaran yang menggunakan metode eksperimen dengan yang menggunakan pembelajaran konvensional. Dapat dilihat pada tabel berikut:

\section{Uji Independen Antara Dua Faktor}

Tabel 4.5 Ringkasan Nilai Uji Independen Antara Dua Faktor

\begin{tabular}{|l|c|c|c|c|}
\hline \multicolumn{1}{|c|}{ Pembelajaran } & B & $\mathrm{K}$ & $x^{2}$ & $X^{2}{ }_{(0,95)(2)}$ \\
\hline Metode Eksperimen & & & & \\
\hline Pembelajaran Konvensional & 2 & 3 & 7,63 & 5,99 \\
\hline
\end{tabular}

\section{Berdasarkan perhitungan} statistik yang dilakukan pada uji independen antara dua faktor yang dilakukan pada kelas yang menggunakan metode eksperimen dan kelas yang menggunakan pembelajaran konvensional diperoleh nilai $x^{2}=$ $7,63>x_{(0,95)(2)}^{2}$. Maka berdasarkan kriteria pengujian statistik $H_{1}$ diterima sehingga dapat disimpulkan ada pengaruh penggunaan metode eksperimen terhadap hasil belajar siswa pada mata pelajaran IPA materi sifatsifat cahaya di kelas V SD Negeri 101790 Marindal II Kecamatan Patumbak .

\section{Pembahasan Penelitian}

Penelitian telah dilaksanakan di SD Negeri 101790 Marindal II Kecamatan Patumbak. Peneliti mengambil dua kelas V-a dan V-b yang berjumblah 51 orang. Langkah awal yang dilakukan adalah melakukan pre test di kedua kelas. Tujuan dari pre test yaitu untuk mengetahui kemampuan awal siswa, maka didapat nilai rata-rata untuk kelas V-a adalah 24,68 dan ratarata kelas V-b adalah 21,07, berdasarkan nilai rata-rata dapat disimpulkan kemampuan siswa kelas V-a dan V-b dapat dikatakan sama atau setara.

Setelah dilakukan pre test maka langkah selanjutnya adalah melakukan pembelajaran, pembelajaran yang akan menggunakan metode eksperimen dan pembelajaran konvensional, maka untuk memilih kelas mana yang akan menggunakan metode eksperimen dan kelas mana yang menggunakan pembelajran konvensional cara yang dilakukan yaitu dengan mengundi, melalui hasil undian maka akan ditetapkan kelas mana yang akan menggunakan metode eksperimen dan pembelajaran konvensional. Hasil yang diperoleh dari pengundian adalah kelas $\mathrm{V}-\mathrm{a}$ yang menggunakan metode eksperimen dan kelas V-b menggunakan pembelajaran konvensional.

Setelah pembelajaran telah dilakukan di kelas yang menggunakan metode eksperimen dan kelas yang menggunakan pembelajaran konvensional maka tahap terakhir dari setiap pembelajaran dilakukan post test, yang bertujuan untuk mengetahui apakah ada pengaruh metode eksperimen terhadap hasil belajar siswa. Dapat dilihat dari hasil rata-rata kelas yang mengguakan metode eksperimen 
adalah 76,80 dan hasil nilai rata-rata kelas yang menggunakan pembelajaran konvensional adalah 62,42 .

Setelah dilaksanakan kedua pembelajaran tersebut ternyata kelas yang diajarkan dengan menggunakan metode eksperimen lebih baik, karena suatu cara penyajian pelajaran dimana siswa dapat mengalami dan melakukan percobaan sendiri. Hal ini sesuai dengan kelebihan metode eksperimen yakni: (1) Membuat siswa lebih percaya atas kebenaran atau kesimpulan berdasarkan percobaan; (2) Dapat membina siswa untuk membuat terobosan-terobosan baru dengan penemuan dari hasil perobaan dan bermanfaat bagi kehidupan manusia; (3) Hasil-hasil percobaan yang berharga dapat dimanfaatkan untuk kemakmuran umat manusia.

Sedangkan kelas yang diajarkan dengan pembelajaran konvensional siswa bersifat pasif, guru kurang memperhatikan siswa, dan siswa kurang berinteraksi antara siswa yang satu dengan yang lain dan siswa kurang cepat memahami dalam melaksankan pembelajaran.

Selanjutnya setelah memperoleh nilai rata-rata data tersebut diuji dengan normalitas data dan menggunakan lilliefors kelas yang menggunakan metode eksperimen dan kelas yang menggunakan pembelajaran konvensional. Untuk post test menggunakan metode eksperimen diperoleh: $\quad L_{0}=0,1207<$ $L_{(0,05)(25)}=0,173$ karena $L_{0}<L_{(0,05)(25)}$ kesimpulan $H_{1}$ diterima maka dapat dinyatkan data berdistribusi normal.

Selanjutnya uji homogenitas varians pada kelas yang menggunakan metode eksperimen dan yang menggunakan

konvensional Hasil paj homogenitas varians diperoleh $F=1,65$ karena $F_{(0,05)(24,25)}$ terdapat pada nilai tabel distribusi $\mathrm{F}$ untuk pembilang dan penyebut maka $F_{(0,05)(24,25)}=1,96$ karena $F=1,65<F_{(0,05)(24,25)}=1,96$ $<x^{2}{ }_{(0,95)(3)}$ maka $H_{0}$ diterima dalam taraf nyata 0,05 sehingga dapat disimpulkan bahwa data post test dinyatakan homogen. Selanjutnya dapat dilanjutkan menggunakan rumus independen antar dua faktor maka diperoleh post tes yaitu $x^{2}=7,63>$ $x^{2}{ }_{(0,95)(2)}=5,99$ dari $x^{2}$ lebih besar dari $x^{2}(0,95)(2)$. Sehingga dapat disimpulkan bahwa hasil belajar siswa pada mata pelajaran IPA materi sifatsifat cahaya menggunakan metode eksperimen lebih baik daripada menggunakan pembelajaran konvensional dikelas V SD Negeri 101709 Marindal II.

Maka dapat dikatakan dengan menggunakan metode eksperimen lebih baik daripada menggunakan pembelajaran konvensional. Hal tersebut dikarnakan bahwa dalam pembelajaran menggunakan metode eksperimen memberikan kesempatan kepada siswa secara perseorangan atau kelompok untuk melatih melakukan suatu proses percobaan secara mandiri. Melalui metode ini siswa sepenuhnya terlibat antara lain dalam merencanakan eksperimen dan menemukan fakta.

\section{Simpulan}

Berdasarkan analisis data dan pengujian hipotesis penelitian yang dilaksanakan di SD Negeri 101790 Marindal II Kecamatan Patumbak dapat disimpulkan sebagai berikut. (1) Hasil belajar siswa pada mata pelajaran IPA materi sifat-sifat cahaya dengan menggunakan metode eksperimen di kelas V SD Negeri 101790 Marindal II Kecamatan Patumbak telah memperoleh nilai rata-rata 76,80. (2) Hasil belajar siswa pada mata pelajaran IPA materi sifat-sifat cahaya dengan menggunakan pembelajaran konvensional di kelas $\mathrm{V}$ SD Negeri 101790 Marindal II Kecamatan Patumbak telah memperoleh nilai rata-rata 62,42. (3) Hasil belajar siswa pada mata pelajaran IPA materi sifat-sifat cahaya menggunakan metode eksperimen lebih baik daripada menggunakan pembelajaran konvensional di kelas V SD Negeri 101790 Marindal II Kecamatan Patumbak. 


\section{DAFTAR PUSTAKA}

Asep Jihad. 2013. Evaluasi pembelajaran. Yogyakarta: Multi Pressindo.

Aqib Zainal. 2016. Kumpulan Metode Pembelajaran. Bandung: PT Sarana Tutorial Nurani Sejahtera.

Bahri Syaiful. 2014. Strategi Belajar Mengajar. Jakarta: PT Rineka Cipta.

Citra Umbara. 2016. Undang-undang RI Nomor 2013 tentang sisdiknas dan peraturan-peraturan RI Tahun 2015 tentang Standar Nasional Pendididkan serta Wajib Belajar.Bandung: Citra Umbara.

Dimyati. 2013. Belajar dan Pembelajaran. Jakarta: PT Rineka Cipta.

Djamarah Syaiful Bahri dkk. 2006. Starategi Belajar Mengajar. Jakarta:Rineka Cipta.

Hamalik Oemar. 2016. Kurikulum dan Pembelajaran. Jakarta: Bumi Aksara.

Hamdani. 2017. Strategi Belajar Mengajar. Bandung: CV Pustaka Setia.

Kresma. 2014. Perbandingan Pembelajaran Konvensional dan Pembelajaran Berbasis Masalah Terhadap Titik Jenuh Siswa Maupun Hasil Belajar Siswa Dalam Pembelajaran Matematika. Mandala Maidun: education Vilae.

Ngalimin. 2017. Strategi Pembelajaran. Yogyakarta: Parama Ilmu.

Purmanto. 2013. Evaluasi Hasil Belajar. Yogyakarta: Pustaka Pelajar.

Slameto. 2015. Belajar dan Faktorfaktor yang Mempengaruhi. Jakarta: PT Rineka Cipta.

Sugiyono. 2016. Statistika Untuk Penelitian. Bandung: Alfa Beta.
Sudjana. 2016. Metode Statistika. Bandung: PT Taristo.

Sumiati. 2013. Metode Pembelajaran. Bandung: CV Wacana Prima.

Trianto. 2015. Desain Pembelajaran Terpadu. Jakarta: Prenada Media Group.

Fisika, Pembelajaran IPA. 2015. Pengertian sumber cahaya benda gelap dan sifatsifatnya. Diakses pada 25 januari dari www.berpendidikan.com/201 5/12/pengertian-sumber-cahayabenda-gelap-dan-sifat-sifatnyacahaya.

Heryansyah, Tedi. 2017. Mengenal macam-macam sifat cahaya. Diakses pada 25 Januari 2018 dari Https://blog.ruangguru.com/meng enal-macam-macam-sifat-cahaya.

Puspita, Nisa. 2015. Sifat-sifat cahaya Diakses pada 25 Januari 2018 dari Https://nisapuspitamawati.wordpr ess.com/2015/06/06/sifat-sifat cahaya/. 